\title{
UPAYA MENINGKATKAN KEAKTIFAN DAN PRESTASI BELAJAR MENGGUNAKAN MEDIA TEKA-TEKI SILANG DENGAN MODEL PEMBELAJARAN TALKING STICK POKOK BAHASAN EKOSISTEM KELAS VII SMPN 1 KARTOHARJO
}

\author{
Candra Puspitasari ${ }^{1)}$, Joko Widiyanto ${ }^{2)}$ \\ ${ }^{1,2)}$ Program Studi Pendidikan Biologi FPMIPA IKIP PGRI Madiun \\ email : candrapuspitasari79@yahoo.com ${ }^{1)}$, joko_widiyanto@ymail.com ${ }^{2}$ ) \\ Diterima 28 Desember 2015, Disetujui 2 Maret 2016
}

\begin{abstract}
The purpose of the study was to determine the activity and student achievement on the material using instructional media ecosystem crossword puzzle with Talking Stick models. This research is a classroom action research (CAR) conducted at SMP Negeri 1 Kartoharjo, with the object of research students VIIE class with 15 students. Data collection is done is by testing, observation and documentation in the form of a check list. The research process was conducted in two cycles each includes four stages, namely planning, implementation, observation and reflection stages. In the present study showed an increase in activity and student achievement in learning biology. It can be seen from the increase in the number of students who completed the $\mathrm{KKM}$ is $\geq 75$. In the student activity before any action there are 3 students (20\%), following the cycle I increased to 7 students $(46.6 \%)$, the second cycle to 13 students $(86.6 \%)$ completed. On student achievement also increased the number of students who completed the pre cycle, the first cycle to the second cycle. Pre cycle 5 students $((33.3 \%)$, after the first cycle of action has increased there are 8 students $(53.3 \%)$, the second cycle, there were 13 students $(86.6 \%)$ completed. Improved completeness KKM students make the mean value the average grade also increased from 54.0 to 70.6 before and increased to 84.3. improvement in cognitive aspects seen from the results of the post test showed increased learning achievement siswayang biology. Can be seen from the increase in the percentage of students completeness, ie the cycle I as much as $53.3 \%$ to $86.6 \%$ in the second cycle. Based on these studies it can be concluded that by using a learning model dengann Talking Stick media crossword puzzles can increase the activity of class and student achievement VIIE SMP Negeri 1 Kartoharjo.
\end{abstract}

Keywords: models of learning talking stick, crossword, student activitity and achievement of learning

\section{PENDAHULUAN}

Berbagai upaya yang dilakukan guru disekolah untuk meningkatkan hasil belajar siswa sehingga tujuan pendidikan dapat tercapai. Salah satunya adalah guru harus terampil menggunakan pendekatan pembelajaran pada saat proses belajar mengajar berlangsung. Pembelajaran merupakan suatu peristiwa yang ingin dicapai setelah siswa mengalami proses belajar. Tujuan pembelajaran tercapai tidaknya dapat terlihat dari prestasi belajar yang diraih oleh siswa. Prestasi siswa yang tinggi menjadi indikasi bahwa siswa tersebut berpengetahuan baik (Syaiful, 2012). Guru dalam proses pendidikan, merupakan salah satu faktor yang menentukan keberhasilan siswa. Guru dalam proses belajar mengajar tidak hanya dituntut agar mampu menyampaikan materi pelajaran dan menguasai bahan pelajaran, tetapi harus dapat mengaktifkan siswa dalam proses belajar mengajar (Hamid, 2010). Suatu pengajaran akan bisa 
disebut berjalan dan berhasil secara baik, manakala ia mampu mengubah diri peserta didik dalam arti yang luas serta mampu menumbuh kembangkan kesadaran peserta didik untuk belajar, sehingga pengalaman yang diperoleh peserta dididk selama ia terlibat di dalam proses pengajaran itu, dapat dirasakan manfaatnya secara langsung bagi perkembangan pribadinya (Ahmad Rohani, 2004).

Media pembelajaran merupakan salah satu sarana yang membantu dalam proses belajar mengajar. Adanya media pembelajaran dapat meningkatkan kualitas proses belajar mengajar menjadi lebih efektif dan efisien sehingga mempermudah peserta didik dalam proses pemahaman materi pelajaran. Harjanto (2011) mengatakan kedudukan media pendidikan sebagai alat bantu mengajar yang ada dalam komponen metodologi, sebagai salah satu lingkungan belajar yang diatur oleh guru. Media pendidikan dapat mempertinggi proses belajar mengajar siswa dalam pengajaran yang pada gilirannya diharapkan dapat mempertinggi hasil belajar yang dicapainya.

Menurut Ngalimun (2012) talking stick sintaknya adalah guru menyiapkan tongkat, sajian materi pokok, siswa membaca materi lengkap pada wacana, guru mengambil tongkat dan memberikan tongkat kepada siswa dan siswa yang kebagian tongkat menjawab pertanyaan dari guru, tongkat diberikan kepada siswa lain dan guru memberikan pertanyaan lagi dan seterusnya, guru membimbing kesimpulan, refleksi dan evaluasi. Kegiatan pembelelajaran talking stick merupakan kegiatan yang sangat menyenangkan, karena masing-masing siswa dapat bermain dengan berinteraksi dengan teman-temannya.

Menurut Purba (dalam Sriyana 2012) teka-teki silang sebagai sebuah permainan yang cara permainannya dilakukan dengan cara mengisi ruang-ruang kosong yang berbentuk kotak dengan huruf-huruf sehingga membentuk sebuah kata yang sesuai dengan petunjuk. Teka teki silang melibatkan partisipasi peserta didik aktif sejak kegiatan pembelajaran dimulai. Peserta didik diajak untuk turut serta dalam semua proses pembelajaran, tidak hanya mental akan tetapi juga melibatkan fisik. Peserta didik akan merasakan suasana yang lebih menyenangkan sehingga hasil belajar dapat dimaksimalkan. Belajar dengan santai inilah yang dapat membuat siswa menjadi paham dan mudah masuk dalam ingatan siswa sehingga siswa tidak mudah lupa dengan materi yang sudah diajarkan. Adanya media teka teki silang diharapkan dapat membantu peserta didik dalam mengatasi kesulitan belajar, dan meningkatkan prestasi belajarnya.

Berdasarkan hasil observasi dan wawancara guru bidang IPA (Biologi) di SMPN 1 Kartoharjo. Karakteristik peserta didik khususunya kelas VII adalah cenderung pasif pada saat pembelajaran berlangsung, lebih suka mendengarkan atau ramai dengan teman sebangkunya. Kondisi tersebut, hanya siswa yang memiliki kemampuan akademis tinggi yang mampu menerima materi yang disampaikan oleh guru, sedangkan siswa yang kemampuan akademis rendah belum maksimal untuk menerima materi. Hasil prestasi belajar siswa khususnya mata pelajaran biologi kelas VII masih tergolong rendah, nilai rata-rata ulangan harian siswa adalah 65. Sejumlah 15 siswa, 10 siswa dengan presentase $66,66 \%$ mendapat nilai di bawah 75 yang merupakan Standar Ketuntasan Belajar Minimal (SKBM) di SMPN 1 Kartoharjo tahun pelajaran 2013/2014. Kondisi tersebut belum bisa dikatakan tuntas secara klasikal, karena dari 15 siswa yang mencapai nilai $\geq 75$ hanya5 siswa dengan presentase $33,33 \%$. Suatu kelas dikatakan tuntas apabila yang mencapai nilai $\geq 75$ mencapai $85 \%$. Model pembelajaran yang sering digunakan 
dikelas VII SMPN 1 Kartoharjo pada saat proses pembelajaran adalah model cooperative learning.

Guru mengajak siswa untuk berdiskusi dalam memecahkan suatu permasalahan. Selain itu guru biasanya juga mengajak siswa melakukan eksperimen untuk membuktikan suatu kejadian. Jarang sekali guru menggunakan model pembelajaran dengan permainan. Guru mengajak siswa bermain, itupun permainannya hanya kuis. Pada saat berdiskusi hanya siswa yang aktif yang mengerjakan sedangkan siswa yang kurang aktif hanya ramai dengan teman lainnya. Diperoleh data keaktifan peserta didik yaitu $33 \%$ peserta didik belum aktif dalam menjawab pertanyaan yang diberikan oleh guru. Tujuan pembelajaran yang lebih baik dibutuhkan suatu media pembelajaran yang dapat digunakan untuk memfasilitasi aktivitas belajar peserta didik. Salah satu media pembelajaran yang dapat digunakan untuk mengatasi permasalahan diatas dengan melalui media teka teki silang.

Berdasarkan kondisi kelas VII di SMP 1 Kartoharjo perlu diadakan upaya untuk meningkatkan keaktifan dan prestasi belajar siswa pada kelas VII SMP 1 Kartoharjo. Penggunaan model dan media pembalajaran yang aktif, kreatif dan inovatif perlu dilakukan agar tercipta kondisi yang menyenangkan bagi peserta didik. Penggunaan media pembelajaran dengan permainan diharapkan dapat meningkatkan keaktifan dan prestasi belajar.

\section{METODE PENELITIAN}

Penelitian yang dilakukan adalah penelitian tindakan kelas (PTK) merupakan suatu penelitian yang dilakukan oleh guru dengan cara merancang, melaksanakan, mengamati dan merefleksikan tindakan secara kolaboratif yang berpartisipatif yang bertujuan untuk memperbaiki atau meningkatkan mutu pembelajaran dikelas melalui tindakan yang terancang dalam suatu siklus (Suharsimi Arikunto, 2006). Indikator kinerja yang digunakan dalam penelitian adalah:

\section{Indikator kinerja keaktifan siswa}

Keaktifan siswa dalam mengikuti kegiatan belajar mengajar dengan menggunakan media teka-teki silang dapat dilihat dari lembar observer yang berupa check list. Indikator keaktifan siswa dalam menjawab pertanyaan yang diadopsi dari Desi (2009) yaitu: a). keaktifan siswa dalam bertanya, b) keberanian siswa dalam mengungkapkan pendapat, c) ketepatan dalam memberikan jawaban. Dikatakan tercapai jika $75 \%$ dari seluruh peserta didik mencapai nilai minimal sebesar $\geq 75$.

2. Indikator kinerja prestasi siswa

Prestasi siswa diukur dengan menggunakan postes dalam bentuk soal esay yang diberikan pada akhir pembelajaran. Postes tersebut diberikan dari 3 soal yang bobot soalnya berbedabeda yaitu soal pertama dengan indikator menjelaskan pengertian ekosistem, soal kedua dengan indikator menjelaskan satuan makhluk hidup dalam ekosistem, soal ketiga dengan indikator menjelaskan urutan rantai makanan dan jaring-jaring makanan dengan tepat.

\section{Teknik Analisis Data}

Analisis data dilakukan selama dan setelah pengumpulan data. Proses analisa data diawali dengan pengumpulan data yang diperoleh dari reduksi data yaitu dengan kegiatan memfokuskan, menyederhanakan dan dari display data yaitu data yang diperoleh dari reduksi data disajikan dalam bentuk deskripsi, tabel atau grafik. Data yang sudah diperoleh 
kemudian dipaparkan untuk menarik kesimpulan. Data yang dianalisis berupa:

1. Data Prestasi Belajar Siswa

Penilaian ini dilakukan untuk mengetahui prestasi siswa, setelah proses belajar mengajar berlangsung indicator proses keberhasilan aspek kognitif secara individu siswa dinyatakan tuntas apabila mendapat nilai $\geq 75$ sesuai dengan SKBM pengukuran prestasi siswa secara individu dapat dihitung dengan rumus sebagai berikut.

Nilai ketuntasan $=\frac{\Sigma \text { skor yang diperoleh }}{\Sigma \text { skor } \text { maksimal }} \times 100$

Setelah indikator ketuntasan belajar secara klasikal jika $80 \%$ dari semua jumlah total siswa mendapat nilai $\geq 75$ yang dapat dihitung dengan rumus:

Pencapaian klasikal $=\frac{\Sigma \text { siswa yang tuntas belajar }}{\Sigma \text { siswa }} \times 100 \%$

\section{Data Keaktifan Belajar Siswa}

Data aktifitas belajar siswa dalam pembelajaran menggunakan media teka-teki silang dengan menggunakan model talking stick. Data keaktifan siswa diambil dengan menggunakan lembar observasi yang berbentuk check list. Siswa dinyatakan aktif dalam pembelajaran apabila siswa tersebut mendapatkan nilai $\geq 75$. Nilai keaktifan belajar siswa dapat dihitung dengan rumus:

Keaktifan belajar individu $=\frac{\Sigma \text { skor yang diperoleh }}{\Sigma \text { skor maksimal }} \times 100 \%$

Indikator pencapaian keaktifan belajar peserta didik secara klasikal jika $\geq 75 \%$ dari jumlah siswa mencapai kategori aktif dan sangat aktif yang dihitung dengan rumus.

Ketuntasan klasikal $=$

$\frac{\Sigma \text { peserta didik yang aktif belajar }}{\Sigma \text { jumlah peserta didik }} \times 100 \%$

\section{HASIL DAN PEMBAHASAN}

Penelitian dilakukan dalam 2 siklus dengan empat kali pertemuan pada pokok bahasan ekosistem dan keanekaragaman makhluk hidup. Siklus pertama dengan materi ekosistem sedangkan pada siklus kedua dengan materi keanekaragaman makhluk hidup. Data yang dikumpulkan dalam penelitian ini ada dua macam yaitu data prestasi belajar siswa dan data keaktifan siswa. Prestasi belajar siswa diperoleh dengan nilai post test sedangkan keaktifan siswa diperoleh dari keaktifan siswa dalam menjawab pertanyaan, keberanian siswa dalam menjawab pertanyaan, ketepatan dalam memberikan jawaban dan mengerjakan soal teka-teki silang yang diisi oleh observer selama proses pembelajaran berlangsung.

\section{Pra Siklus}

Penelitian menggunakan obyek sebanyak 15 siswa pada kelas VII E. Nilai keadaan siswa yang digunakan yaitu nilai semester 1 (satu) sebelum dilakukan penelitian. Berdasarkan hasil nilai semester satu dapat diketahui bahwa sebanyak 5 siswa $(33,33 \%)$ dinyatakan tuntas sedangkan 10 siswa $(66,66 \%)$ dinyatakan belum tuntas (Tabel 1).

Tabel 1. Nilai Semester 1 Prestasi belajar siswa sebagai data awal

\begin{tabular}{ccc}
\hline Kategori & Sumlah \\
& Siswa & Persen $(\%)$ \\
\hline Tuntas & 5 & 33,33 \\
Belum & 10 & 66,66 \\
Tuntas & & 100 \\
Jumlah & 15 & 10 \\
\hline
\end{tabular}

Berdasarkan nilai rata-rata prestasi belajar siswa, nilai rata-rata prestasi belajar siswa mulai dari pra siklus, siklus I sampai siklus II mengalami banyak peningkatan sebesar 53,36. Pada siklus II pembelajaran sudah berhasil karena baik klasikal dan individu sudah memenuhi target yaitu diatas ketuntasan klasikal sebesar 86,6\%. 
Keberhasilan ini dikarenakan guru telah berusaha meningkatkan kinerja mengajar dengan membuat kondisi menyenangkan sehingga membuat siswa tertarik untuk belajar, memberikan motivasi kepada siswa dan penyampaian materi yang jelas dan terarah disertai dengan media teka-teki silang (Tabel 2).

Tabel 2. Prestasi Belajar Siswa

\begin{tabular}{|c|c|c|c|c|}
\hline \multirow[b]{2}{*}{ Kategori } & \multicolumn{2}{|c|}{ Jumlah } & \multirow[b]{2}{*}{$\%$} & \multirow{2}{*}{$\begin{array}{l}\text { Peningk } \\
\text { atan }\end{array}$} \\
\hline & $\begin{array}{l}\text { Siswa } \\
\text { Tuntas }\end{array}$ & $\begin{array}{c}\text { Rata- } \\
\text { rata }\end{array}$ & & \\
\hline Pra Siklus & 5 & 54,0 & 33,3 & \\
\hline Siklus I & 8 & 70,6 & 53,3 & \\
\hline Siklus II & 13 & 84,3 & 86,6 & $53,36 \%$ \\
\hline
\end{tabular}

Berdasarkan nilai rata-rata keaktifan belajar siswa pra siklus sangat rendah yaitu $20,0 \%$ dan jauh dari SKM yaitu $\geq 75$, untuk siklus I dan siklus II mengalami peningkatan yaitu $46,6 \%$ menjadi $86,6 \%$ (Tabel 3).

Tabel 3. Keaktifan Belajar Siswa

\begin{tabular}{|c|c|c|}
\hline \multirow{2}{*}{ Kategori } & \multicolumn{2}{|c|}{ Jumlah } \\
\hline & Skor & $\%$ \\
\hline Pra Siklus & 3 & 20,0 \\
\hline Siklus I & 7 & 46,6 \\
\hline Siklus II & 13 & 86,6 \\
\hline
\end{tabular}

dilaksanakan dengan 2 siklus yaitu siklus I dan siklus II. Selama kegiatan belajar mengajar pada siklus I dan siklus II ternyata mengalami penigkatan baik pada keaktifan siswa maupun hasil belajar siswa. Berikut ini merupakan perbandingan hasil dari siklus I dan siklus II. Berdasarkan analisis belajar siswa pada siklus II dapat diketahui bahwa terjadi perkembangan yang cukup baik dalam kegiatan belajar mengajar siswa. Untuk mengetahui perkembangan hasil belajar siswa dari pra siklus, siklus I sampai siklus II dapat dilihat pada Gambar 1 sebagai berikut.

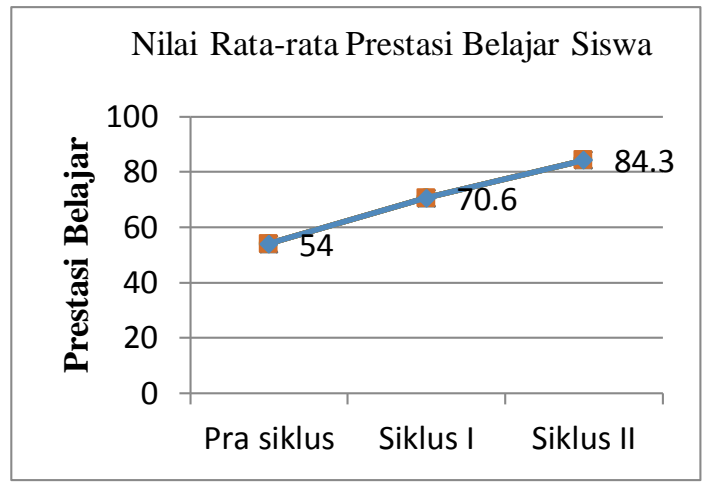

Gambar 1. Perbandingan Prestasi Belajar Siswa Pada Kondisi Awal, Siklus I, Siklus II

Berdasarkan grafik dapat diketahui bahwa nilai rata-rata prestasi belajar siswa pada pra siklus sangat rendah yaitu 54,0. Setelah dilakukan pembelajaran dengan menggunakan model talking stick berbantu media teka-teki silang ternyata mengalami banyak peningkatan pada siklus I yaitu 70,6 sedangkan pada siklus II juga mengalami banyak peningkatan dengan nilai rata-rata prestasi belajar siswa yaitu 84,3 dengan ketuntasan klasikal 86,6\%. Nilai prestasi belajar siswa yang diperoleh sudah memenuhi Standar Ketuntasan Belajar Minimal (SKBM) yaitu 75 dengan ketuntasan klasikal sebesar $80 \%$ dari jumlah seluruh siswa mendapat nilai $\geq 75$. Nilai rata-rata prestasi belajar siswa dengan ketuntasan klasikal yaitu sebesar $84,3 \%$ ternyata lebih besar dari nilai klasikal yang ditetapkan. Berdasarkan data, siklus II sudah sesuai indikator ketuntasan, sehingga siklus II dihentikan karena nilai rata-rata belajar siswa sudah mencapai SKBM.

Hasil perolehan prestasi belajar siswa pada pokok bahasan Ekosistem saat siklus I dan siklus II dengan menggunakan model pembelajaran talking stick berbantuan media teka-teki silang ternyata terbukti dapat meningkatan prestasi belajar siswa dan membuat siswa berani untuk 
bertanya jika ada pertanyaan yang dirasa kurang jelas. Pernyataan tersebut sesuai dengan yang dikemukakan oleh Agus Suprijono (2009) bahwa pembelajaran dengan model talking stick dapat mendorong peserta didik untuk berani mengemukakan pendapat. Menurut Purba (dalam Sriyana 2012) bahwa media tekateki silang melibatkan partisipasi peserta didik aktif sejak kegiatan pembelajaran dimulai. Peserta didik diajak untuk turut serta dalam semua proses pembelajaran, tidak hanya mental akan tetapi juga melibatkan fisik. Fungsi dari teka-teki silang yaitu membangun saraf-saraf otak yang memberi efek menyegarkan ingatan sehingga fungsi kerja otak optimal, sedangkan guru hanya sebagai fasilitator dan mengavaluasi proses pembelajaran yang dilakukan oleh siswa.

Data keaktifan siswa dalam pra siklus kelas VII E sangat rendah yaitu $20,0 \%$ dan jauh dari SKM yaitu $75 \%$. Kondisi tersebut dikarenakan siswa lebih asyik bermain dengan teman sebangkunya atau siswa lebih berdiam diri tanpa mendengarkan penjelasan dari guru pada saat proses pembelajaran berlangsung. Setelah dilakukan pembelajaran dengan model talking stick berbantu media tekateki silang siswa menjadi aktif dan keaktifan siswa mengalami peningkatan yang cukup banyak. Adapun keaktifan siswa selama kegiatan belajar mengajar baik pada pra siklus, siklus I maupun siklus II dapat dilihat pada Gambar 2.

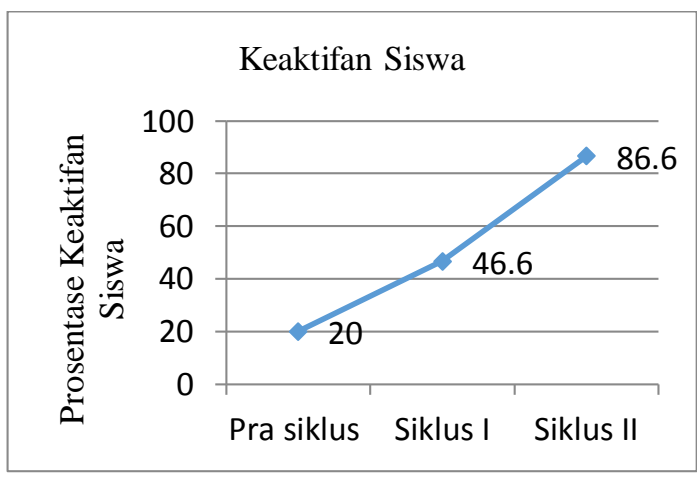

Gambar 2. Keaktifan Siswa
Berdasarkan gambar menunjukkan bahwa pada saat kondisi awal atau bisa dikatakan pra siklus nilai rata-rata keaktifan siswa yaitu 20,0\% hal ini jauh dari standar ketuntasan minimal yaitu $\geq 75$. Namun pada pertemuan selanjutnya mengalami peningkatan yang cukup banyak. Tahapan paling aktif yaitu pada saat siklus II dengan permainan teka-teki silang. Siklus I sebesar 46,6 \% aktif dalam melakukan permainan teka-teki silang, sedangkan pada siklus II pertemuan keempat mengalami peningkatan menjadi 86,6\%. Pembelajaran dengan menggunakan model pembelajaran talking stick berbantu media teka-teki silang mampu meningkatkan keaktifan siswa yang ditandai banyaknya siswa aktif bertanya, berani mengungkapkan pendapat dan mengerjakan teka-teki silang didepan kelas sehingga dapat meningkatkat nilai rata-rata keaktifan siswa. Karena dengan media teka-teki silang siswa menjadi tertantang, teliti dan berpikir lebih luas untuk mengerjakan soal tersebut, selain itu media teka-teki silang sifatnya permainan sehingga membuat siswa lebih nyaman sehingga terciptanya suasana belajar yang sangat menyenangkan.

Nilai keaktifan siswa yang diperoleh sudah memenuhi nilai SKM yaitu $\geq 75$ dengan ketuntasan klasikal 86,6\%. Ternyata nilai ketuntsan klasikal lebih besar dari indikator ketercapaian yang telah ditetapkan. Permainan teka-teki silang yang dirancang dalam penelitian ini ternyata membuat siswa lebih rilexs, aktif dan tidak merasa bosan dalam mengikuti kegiatan belajar mengajar.Masing-masing siswa saling berlomba untuk mengerjakan dan menjawab pertanyaan yang ada dalam teka-teki silang. 


\section{KESIMPULAN DAN SARAN}

\section{Simpulan}

Berdasarkan hasil analisis data dan temuan-temuan yang diperoleh dari penelitian tindakan kelas dapat disimpulkan bahwa pembelajaran dengan menggunakan model pembelajaran Talking Stick dengan menggunakan media tekateki silang dapat meningkatkan prestasi belajar dan keaktifan siswa kelas VIIE SMP Negeri 1 Kartoharjo Tahun Pelajaran 2013/2014.

\section{Saran}

Alokasi waktu untuk setiap tahapan pembelajaran dalam model talking stick dengan media teka-teki silang perlu diperhitungkan dengan tepat sehingga semua tahapan dapat dilaksanakan dengan baik. Kepada peneliti lain. Hasil penelitian tersebut dapat digunakan sebagai bahan rujukan atau bahan pembanding untuk diadakan penelitian selanjutnya mengenai keefektifan penggunaan model pembelajaran talking stick berbantu media teka-teki silang bila diterapkan pada mata pelajaran lain dalam meningkatkan prestasi belajar dan keaktifan siswa. Penggunaan model pembelajaran talking stick dengan model pembelajaran lain untuk mengetahui perbandingannya agar teori ini benar-benar teruji keefektifannya.

\section{DAFTAR PUSTAKA}

Ahmad, Rohani. (2004). Pengelolaan Pengajaran. Jakarta: PT Asdi Mahasatya.

Harjanto. (2011). Perencanaan Pengajaran. Jakarta: PT Rineka Cipta.

Ngalimun. (2013). Strategi dan Model Pmbelajaran. Yogyakarta: Aswaja Pressindo.
Suharsimi, Arikunto. (2006). Penelitian Tindakan Kelas. Jakarta: PT Bumi Aksara.

Sriyana. (2013). Pengaruh Media Pembelajaran Teka-Teki Silang (TTS) Dengan Model Pembelajaran Cooperative Learning Terhadap Tingkat Berpikir Pada Siswa SMP. Skripsi (online) http://library.ikippgrismg.ac.id. Diakses t 24 Februari 2014

Syaiful, Bahri Djamarah. (2012). Prestasi Belajar dan Kompetensi Guru. Surabaya: Usaha Nasional 